\title{
Querela das Mulheres, Igualdade e Direito à Educação: França, 1399 a 1793
}

\author{
Alceu Ravanello Ferraro' \\ 'Universidade Federal do Rio Grande do Sul (UFRGS), Porto Alegre/RS - Brasil \\ RESUMO - Querela das Mulheres, Igualdade e Direito à Educação: França, \\ 1399 a $1793^{1}$. Este artigo trata da relação da querela das mulheres com a \\ igualdade entre os sexos no que se refere ao direito à educação, definindo- \\ se como campo de investigação a França, nos quase quatro séculos que vão \\ de 1399 à Revolução Francesa, com distinção de três períodos de criação \\ cumulativa: o de Christine de Pizan, a primeira mulher a viver da sua pena \\ e a sustentar com ela a sua família; o de Marie de Gournay e Poulain de la \\ Barre, que elevaram o termo igualdade a conceito e princípio; e o do mar- \\ quês de Condorcet e Olympe de Gouges, que enriqueceram o conceito de \\ igualdade com o de universalidade, estendendo a todos os seres humanos \\ (Condorcet) e aos negros (Condorcet e Gouges) todos os direitos reivindica- \\ dos para as mulheres. \\ Palavras-chave: Educação. Direito das Mulheres. Igualdade de Gênero.
}

ABSTRACT - The Woman Question, Equality, and the Right to Education: France, 1399 to 1793. This article explores the relationship between the woman question and equality between the sexes regarding the right to education. The research was centered in France, from 1399 to the French Revolution. Three periods of cumulative creation were defined: that of Christine de Pizan, the first woman to live by her pen and support her family with it; that of Marie de Gournay and Poulain de la Barre, who elevated the term equality to a concept and principle; and that of the Marquis of Condorcet and Olympe de Gouges, who enriched the concept of equality with that of universality, thus extending to all human beings (Condorcet) and specifically to blacks (Condorcet and Gouges) all the rights claimed for women. Keywords: Education. Women's Rights. Gender Equality.

Educação \& Realidade, Porto Alegre, v. 46, n. 3, e113918, 2021.

http://dx.doi.org/10.1590/2175-6236113918 
Querela das Mulheres, Igualdade e Direito à Educação

\section{Introdução}

Inicia-se trazendo à memória algumas contribuições que ajudaram na definição do objeto e do método da investigação de que resultou este trabalho.

Tem-se, em primeiro lugar, no final do primeiro terço do século XX, a seguinte afirmação do jurista brasileiro Pontes de Miranda (1933a, p. 39), em seu opúsculo Direito à Educação: "O direito à educação é filho dos Séculos, mas nasceu [...] nos nossos dias”. Um direito, portanto, nascido há menos de um século, mas depois de uma gestação multissecular.

Dá suporte a essa afirmação de Pontes de Miranda o sociólogo inglês T. H. Marshall (1967, p. 63-66), quando apresenta um conceito tripartido de cidadania, com três elementos: o elemento civil (direitos civis), o elemento político (direitos políticos) e o elemento social (direitos sociais), atribuindo, com a devida elasticidade, o período de formação de cada um deles respectivamente aos séculos XVIII, XIX e XX, observando ainda que o sistema educacional e os serviços sociais são as instituições mais intimamente ligadas com o elemento social.

Tem-se, em segundo lugar, a observação do jurista P. Bonavides (2017, p. 578, grifos meus), de que os direitos sociais, culturais e econômicos, bem como os direitos coletivos ou de coletividades, que, germinados por obra da ideologia e da reflexão antiliberal, foram introduzidos no constitucionalismo das distintas formas de Estado social, "Nasceram abraçados ao princípio da igualdade, do qual não se podem separar, pois fazê-lo equivaleria a desmembrá-los da razão de ser que os ampara e estimula". Na mesma direção, referindo-se à tríade famosa da Revolução Francesa, Comparato (2015, p. 148) entende que "foi sem dúvida a igualdade que representou o ponto central do movimento revolucionário". Tratar, pois, do direito à educação é, forçosamente, tratar também do princípio da igualdade.

Em terceiro lugar, o autor da obra François Poulain de La Barre and the invention of modern equality (Francisco Poulain de La Barre e a invenção da moderna igualdade) defende a tese de que o significado histórico de Poulain, particularmente em seu primeiro livro, intitulado De l'égalité des deux sexes (Da igualdade dos dois sexos), de 1673, está "no fato de ele ter formulado uma filosofia igualitária sistemática, na qual, pela primeira vez, a ideia da igualdade natural de todos os seres humanos possuidores de razão é aplicada a todos os tipos de relações sociais", entendendo ainda o autor que Poulain "é talvez o único pensador do século XVII que formulou um conceito verdadeiramente universal de igualdade" (Stuurman², 2004, p. 296, grifo do autor).

Em quarto lugar, Simone de Beauvoir (1980, v. 1, p. 140) diz que Poulain de La Barre concluiu sua obra "reclamando uma sólida instrução para as mulheres”. Pellegrin ${ }^{3}$ (2011, p. 45), por sua vez, observa que, ao contrário de vários autores do final do século XVII que concordavam que a mulher precisava de instrução, mas de uma instrução diferenciada, que conviesse ao seu status, "Poulain articula instrução e emancipação, sendo a primeira o meio privilegiado da segunda”. 
Por fim, em quinto lugar, tem-se a palavra de É. Viennot (2012, p. 7 e 11): "Do fim da Idade Média às primeiras décadas do século XX, a Europa primeiro, depois o mundo que ela influenciava, foram o teatro de uma gigantesca polêmica sobre o lugar e o papel das mulheres na sociedade", polêmica esta que se deu "em torno da dupla questão da igualdade (ou da desigualdade) dos sexos e da diferença (ou similaridade) entre eles", com destaque para "choques entre partidários e oponentes da educação feminina, entre feministas e antifeministas”.

As citações que se acaba de fazer colocam em evidência, de um lado, a emergência da educação como direito social, nascido no século $\mathrm{XX}$, mas gestado durante séculos, e de outro, a multissecular "querela das mulheres" em busca de igualdade de direitos entre os sexos, principalmente quanto àquilo que, para Groult (2010, p. 11), foi "uma reivindicação maior: o acesso à educação”, batalha que, segundo a autora, iria durar séculos.

Quanto à luta por igualdade, há que se lembrar que, em 1962, em seu livro Capitalism and Freedom (Capitalismo e Liberdade), Milton Friedman, renomado economista neoliberal da Universidade de Chicago, queixava-se (reclamava? lamentava?) que as palavras-chave tinham passado a ser, então, "bem-estar e igualdade, em vez de liberdade".

Para o autor, contrariamente ao liberal do século XIX, que "considerava a extensão da liberdade como o meio mais efetivo de promover o bem-estar e a igualdade", o liberal do século XX passara a considerar o bem-estar e a igualdade "ou como pré-requisitos ou como alternativas para a liberdade", de sorte que este, em nome do bem-estar e da igualdade, acabara "por favorecer o renascimento das mesmas políticas de intervenção estatal e paternalismo contra as quais tinha lutado o liberalismo clássico" (Friedman, 1985, p. 14). Mas há um detalhe a destacar: Friedman ignorava ou não se lembrava que a própria Constituição de Independência dos Estados Unidos, seu país, de 4 de julho de 1776, após parágrafo introdutório, enumera algumas verdades tidas como evidentes por si mesmas, figurando em primeiro lugar, e como que embasando as demais, o princípio da igualdade: "Nós consideramos evidentes por si mesmas as verdades seguintes: que todos os homens são criados iguais, dotados pelo Criador de certos direitos inalienáveis, entre os quais estão a vida, a liberdade e a busca da felicidade" (United States, 1776).

A Declaração dos Direitos do Homem e do Cidadão (1789) da Revolução Francesa coloca os princípios da liberdade e igualdade no mesmo plano: "Artigo $1^{\circ}$. Os homens nascem e permanecem livres e iguais em direitos [...]" (apud Rials, 1988, p. 22).

A questão que essas considerações iniciais suscitam é se essa multissecular querela das mulheres e os temas ali discutidos, com destaque para o da igualdade entre os sexos, contribuíram para a construção daquilo que leva, hoje, o nome de direito à educação.

Para dar pelo menos um começo à busca de uma resposta para esta questão, teve-se presente a hipótese levantada por M. É. Henneau (2015) e o caminho apontado por G. Fraisse (2012). A hipótese de Henne- 
Querela das Mulheres, Igualdade e Direito à Educação

au (2012, p. 9) é que a França teria sido, desde a Idade Média, “o berço da disputa [da querela das mulheres], conferindo-lhe os argumentos e os modos de expressão os mais originais”. Já o método sugerido por Fraisse (2012, p. 163-164) é que a problemática da igualdade dos sexos deve ser tomada em sua temporalidade, donde a autora deduz dois imperativos e uma conclusão metodológica: os dois imperativos são o de "nunca esquecer que a história da emancipação das mulheres é um história longa" e o de "Jamais reduzi-la à repetição de um mesmo protesto"; a conclusão metodológica é que, na observância desses dois imperativos, é necessário "seguir [...] o termo 'igualdade”, termo que significa justamente a exigência e adoção de uma "medida comum entre os sexos". Ora, essa ideia de uma medida comum aponta precisamente para a ideia de igualdade.

Aceita a hipótese de Henneau e adotado o caminho sugerido por Fraisse, optou-se por selecionar algumas figuras-chave nessa querela, todas da França, seja pela sua importância histórica em seu conjunto, seja pela maior disponibilidade bibliográfica, seja ainda pela impossibilidade de, num único artigo, abordar manifestações dessa querela em outros países como Inglaterra, Itália, Alemanha, Holanda, Espanha..., como se tem em volume da coleção École du Genre, organizado por Dubois-Nayt, Henneau e Kulessa (2015) ${ }^{4}$.

Em relação às figuras-chave selecionadas, centrou-se a atenção: a) nos direitos reivindicados para as mulheres; b) na ideia/conceito/princípio da igualdade como fundamento da universalidade de tais direitos; c) nos argumentos invocados em defesa de uma educação/instrução da mulher igual à oferecida aos homens e; d) na possível relação de tudo isso com o que, no século XX, viria a levar o nome de direitos sociais, e, entre estes, o de direito à educação.

Note-se, porém, que seguir o termo "igualdade" no tempo tem suas implicações, pois o conceito e o princípio da igualdade têm sido sempre um elemento de difícil acomodação dentro da doutrina e prática liberais, a ponto de autores liberais que enfatizam a igualdade terem sido acusados de socialismo pelos ultraliberais de diferentes matizes, como os neoliberais.

O que se vem dizendo sobre igualdade é de extrema importância para o desenvolvimento do tema proposto. Isto, porque a afirmação do princípio da igualdade esteve historicamente associada de forma estreita à defesa dos direitos da mulher.

Por fim, resta esclarecer que não se tem aqui um estudo propriamente historiográfico, mas um estudo sociológico que se vale da história.

Inicia-se com a protofeminista Christine de Pizan, no fechamento do século XIV e primeiras décadas do século XV, finalizando-se o percurso com o marquês de Condorcet e Olympe de Gouges ao final do século XVIII, nos anos da Revolução Francesa. 


\title{
Christine de Pizan, Veneza 1363-1430 ou 1431, Poissy/ França
}

Benoîte Groult (2010, p. 18-19) diz que foi somente na Idade Média que emergiu uma tomada de consciência da condição feminina e se pôde ter a formulação de um primeiro corpo de doutrina daquilo que, bem mais tarde, levaria o nome de feminismo ${ }^{5}$. Ainda segundo a autora, foram as mulheres que "esboçaram os primeiros traços, não de uma revolta individual, que já tinha havido no passado, mas de uma revolução que faria justiça a seu sexo por inteiro", tendo sido Christine de Pizan a "primeira mulher a viver de sua pena" e a "dar ao feminismo sua expressão moderna”.

A julgar pelo que explica A. Paupert (2013, p. 24-25), essa primeira tomada de consciência da condição feminina de que fala Groult teria sido precedida, no final da Idade Média, por um "recrudescimento dos temas antifeministas em obras satíricas ou em breves poemas", obras, por vezes, "antimatrimoniais, antes de serem antifeministas". Ainda segundo Paupert (2013, p. 36), Christine de Pizan intervém num momento bem determinado da história - na virada do século XIV para o século XV. A multiplicação de peças, a partir do século XIV, a favor e contra o casamento, a favor e contra as mulheres e, mais ainda, a publicação do conjunto de textos de Jean Le Fèvre e a tradução do latim para o francês das Lamentationes de Mateolus constituíam já "uma maneira de debate".

Mas, segundo a autora, foi com a entrada de Christine em cena que a situação mudou,

\begin{abstract}
Ao se engajar na defesa das mulheres e ao chamar a si a tarefa de refutar um a um os argumentos antifeministas dos seus adversários, e ao levar esse debate perante a corte (a rainha Isabel), e perante um público mais amplo: a sociedade cortesã e leiga, e mais ainda, a todas as mulheres, às quais se dirigiam explicitamente a Cidade e as Três Virtudes, ela [Christine] dava um impulso decisivo àquilo que iria tornar-se a Querela das mulheres. Além disso, é uma mulher que, pela primeira vez, toma a palavra nesse debate, coisa que não se irá repetir senão muito tempo depois (Paupert, 2013, p. 36-37).
\end{abstract}

A "protofeminista” de quem se está falando nasceu em Veneza, em 1363 ou 1364, levando o nome de Cristina da Pisano, e faleceu como Christine de Pizan (também Pisan), em Poissy, na França, em 1430 ou 1431. Tendo ela apenas três anos, seu pai, médico, professor de astrologia na Universidade de Bolonha e conselheiro da República de Veneza, foi nomeado astrólogo, alquimista e médico do rei Carlos V da França, conhecido como "rei sábio" e detentor de uma das principais bibliotecas do mundo cristão. Foi graças ao acesso a essa biblioteca situada no palácio real (Louvre) que Christine pôde satisfazer seus interesses intelectuais, para o que contou com o apoio e incentivo do pai e, depois, também do notário real, Étienne du Castel, com quem se casara. 
Querela das Mulheres, Igualdade e Direito à Educação

Após o falecimento do rei Carlos V em 1380, Christine, aos 24-25 anos de idade, perdeu também o marido, que a deixou com muitas dívidas, e, mais tarde, o pai. Excluindo como alternativa tanto casar-se de novo como recolher-se em algum convento, buscou no uso da pena a própria sobrevivência, assim como a dos seus três filhos, da mãe e de uma sobrinha desamparada, tornando-se conhecida como a primeira mulher a viver da própria pena, isto é, como escritora profissional. Notese: a primeira mulher a fazer do uso da pena uma profissão, não a primeira mulher a fazer uso da pena.

Como poeta da corte, escreveu mais de trezentas baladas. Paupert (2013, p. 29) distingue quatro obras da autora que fazem da defesa das mulheres seu objeto principal: Épistre au Dieu d'Amours (Epístola ao Deus do Amor), de 1399; Épistres du Debat sur le Roman de la Rose (Epístolas do Debate sobre o Romance da Rosa), do início dos quatrocentos; Livre de la Cité des Dames (Livro da Cidade das Damas), de 1404-1405, e Livre des Trois Vertues (Livro das Três Virtudes), de 1405.

Embora se costume datá-lo do início do século XV, entende-se que o protofeminismo de Christine já se fez presente no último ano do século XIV. Com efeito, na acima referida Épistre au Dieu d'Amours, de 1399, a poetisa Christine desencadeou a chamada Querela do Romance da Rosa, onde teceu dura crítica ao referido romance, composto de duas partes: a primeira, de Guillaume de Lloris, aproximadamente de 1230, sobre "toda a arte [cavalheiresca] do amor"; a segunda, bem mais extensa, de Jean de Meun, escrita por volta de 1275, grosseiramente misógina, como nas seguintes passagens:

\begin{abstract}
Um homem rico que se imagine amado tem mais cornos que um veado. [...] Deixa o choro para as mulheres e as crianças pois tratam-se [sic!] de criaturas fracas e inconstantes. [...] Porém, uma vez conquistado o prémio [a rosa], será necessário uma grande perícia para o manteres, isto se dele quiseres desfrutar durante muito tempo, uma vez que manter e proteger as coisas que conquistámos não é sinónimo de uma virtude menor que aquela representada pelo acto da conquista. [...] O certo é que agora já não há nenhuma Lucrécia, nem mesmo uma só Penélope na Grécia, e, caso fôssemos a procurar bem, nem uma só mulher de bem em toda a terra. [...] É por tua causa que estou coberto de vergonha, é por tua causa, por ti e pela tua lascívia, que faço agora parte da confraria de São Arnaldo, o patrono dos cornudos, confraria esta a que, pelo que sei, homem algum que tenha mulher se encontra a salvo [...]. [...] As mulheres não se importam minimamente com coisas como a honra ou a vergonha, sempre que se lhes mete uma ideia na cabeça, já que não se pode duvidar do facto de que as mulheres não sabem nada. [...] As mulheres mostram-se particularmente inconvenientes e maçantes em seus discursos (Meun apud Lloris; Meun, 2001, p. 81; $106 ; 136 ; 142 ; 149 ; 153 ; 298)$.
\end{abstract}

Na referida Épistre ${ }^{6}$, poema com cerca de 830 versos, Christine dirige-se a Cupido, deus do amor, e a todos os seus leais servidores, com as 
palavras "SAÚDE, AMOR, FAMILIARIDADE". Justifica, então, sua epístola dizendo que, na Corte, haviam chegado a ela lamentações e mui doídas queixas de todas as senhoras e senhoritas pedindo humildemente sua ajuda. Diz ainda que tais queixas referiam-se a grandes extorsões, críticas, difamações, traições, ultrajes, falsidades e muitas outras censuras que diariamente as mulheres recebem de [homens/cavalheiros] desleais, que as reprovam, difamam e decepcionam (Pizan, 1399, versos $1-22)$.

E a autora denuncia: "Em todas as localidades elas [as mulheres] se queixam da França, que, no passado, foi seu escudo e defesa, que contra todos as defendeu da injustiça, como é de direito e como deve fazer nosso nobre país onde reina a gentileza" (Pizan, 1399, v. 23-27). E exclama: "Deus, que faladores! Deus, que assembleias onde as honras das senhoras são roubadas!" (Pizan, 1399, v. 163-164). Critica clérigos "que fazem versos, tanto pela tarde como pela manhã, e se fundamentam não se sabe em que livros que dizem mais mentiras do que alguns bêbados" (Pizan, 1399, v. 276-280). Para a poetisa, está mal nomeado o tratado Arte de amar de Ovídio, sendo antes o "livro da arte de enganar [as mulheres]" (Pizan, 1399, v. 376-377).

A seguir, Christine refere-se ao "longo processo", à "coisa difícil", envolvendo "ciências claras e obscuras" e "grandes aventuras" postas por Jean de Meun no Romance da Rosa, para assaltar o castelo - para apoderar-se da Rosa; na realidade, "para enganar sem mais uma donzela" (Pizan, 1399, v. 389-396). E pergunta: "Há necessidade de um grande assalto para [tomar] um lugar sem defesa? Como se pode de tão perto fazer grande assalto? [...] Pois, de que arte, grande engenho e grande esforço se necessita para enganar uma mulher, nobre ou camponesa?" (Pizan, 1399, v. 397-398; 403-404).

Seria no mínimo anacrônico buscar em Christine de Pizan um conceito de igualdade como se iria construir principalmente a partir do século XVII. Mas encontram-se, sim, e já na referida Épistre de 1399, termos e expressões que vão nessa direção, tais como: Dieu la forma à sa digne semblance (Deus a formou à sua digna semelhança); C'est son droit par qui a lui est semblable (É direito seu por lhe ser semelhante); Car nul bon fruit de mal arbre ne vient (Porque nenhum bom fruto se tem de árvore má); Car aux mères bien ressemblent les fieulz (Porque às mães bem se parecem os filhos) (Pizan, 1399, v. 595; 735; 755; 758).

E a autora conclui dizendo que "todos os homens razoáveis devem estimar, tratar com carinho, amar as mulheres, [...] de quem todo homem descende. Trata-se de sua mãe, de sua irmã, de sua amiga" (Pizan, 1399 , v. 722; 723; 733).

Tendo em conta os preconceitos generalizados então em voga contra as mulheres, há que se reter pelo menos cinco pontos importantes: primeiro, o interesse pessoal de Christine pelo estudo e pela escrita (autoria); segundo, o apoio recebido do pai, do marido e de membros da própria corte; terceiro, o privilegiado acesso à biblioteca real; quarto, o falar como mulher e como representante do universo feminino; quinto, o haver feito da educação uma causa de todo o sexo feminino. 
Querela das Mulheres, Igualdade e Direito à Educação

A propósito do lugar da educação na querela das mulheres, Viennot (2012, p. 14) faz uma síntese importante para o que interessa neste artigo:

\begin{abstract}
Enfim, a partir do século XVII, a disputa se concentraria sobre a questão da educação e do acesso das mulheres ao saber, em virtude da ideia, lançada com força por Christine de Pizan em 1404 e retomada em seguida por todos os feministas, segundo a qual, 'Se existisse o costume de enviar as meninas à escola e de ensinar-lhes metodicamente as ciências, como se faz com os meninos, elas aprenderiam e compreenderiam as dificuldades de todas as artes e de todas as ciências tão bem quanto eles'?
\end{abstract}

Foi, pois, Christine de Pizan quem lançou a ideia de se lutar pela educação da mulher, e por uma educação igual à oferecida aos homens, ideia que ganharia força principalmente a partir do século XVII.

O interesse por Christine de Pizan no Brasil veio traduzindo-se recentemente, por exemplo, em tese de doutorado (Calado, 2006) e dissertação de mestrado (Souza, 2013), ambos os estudos sobre a obra $A$ cidade das damas.

Anote-se, porém, que Christine de Pizan não foi nem a primeira mulher, nem a única em seu tempo, a fazer uso da escrita. Foi, ao que se saiba, a primeira a viver da escrita, como já salientado. O que incomodava os misóginos não era apenas o fato de uma mulher entrar no espaço público através da escrita. A entrada no espaço público lhe era simplesmente interditada, não importando a forma - a escrita, o trabalho, a palavra, a música, o teatro... Com efeito, contemporânea de Christine de Pizan, a burguesa inglesa Margery Kempe (1273-1438), por exemplo, mesmo sem domínio da leitura e da escrita, foi severamente importunada, porque, guardando em sua memória singular as leituras que lhe faziam da bíblia e de outras obras, como de Santo Agostinho, atreviase a atuar em público a clériga contestadora, o que lhe valeu, como ela mesma conta em livro ditado a um copista, que, por falar do evangelho, clérigos a dessem por possuída do demônio (Dor, 2015, p. 211-220).

Para Swift (2013 p. 61), se as aberturas na Querela das Mulheres não chegam a por fim ao debate ("o sentido da Rose não será jamais 'totalmente fechado'”), elas "pelo menos colocam a questão das mulheres no coração batente da poética da Idade Média tardia".

\title{
Disputa pela superioridade das mulheres ou dos homens
}

A julgar pelos trabalhos consultados da coleção École du genre, a Querela das Mulheres no período pós-Christine até meados do XVII foi marcada principalmente pela disputa sobre a superioridade das mulheres ou dos homens.

A esse respeito, Fraisse (2012, p.163-4) ressalta que a querela, no período, anunciava a existência de uma polêmica sobre a igualdade dos sexos, onde se afrontavam argumentos invocando as qualidades morais 
e a hierarquia dos valores e se disputava sobre a excelência da mulher ${ }^{8}$ ou do homem, sobre qual dos dois sexos era o melhor; querela que se tornava obstáculo à igualdade, precisamente, por sugerir hierarquia e classificação, implicando necessariamente em desigualdade.

No entanto, essa mesma autora identifica também, nessa querela, um elemento utópico relativamente à ideia de igualdade: "Mas, ao mesmo tempo, ela [a querela] não toma todo seu sentido senão com o surgimento da utopia, justamente da medida comum entre os sexos, que se chama igualdade" (Fraisse, 2012, p. 164). Medida comum de que falava Pizan, como se acabou de ver.

Com efeito, a ideia de igualdade aparece explicitamente nos excertos extraídos da edição de 1556 das obras de Louise Labé (por volta de 1520-1566), que acompanham o artigo de B. Alonso (2013, p. 121-131) sobre essa autora renascentista, mas "igualdade" na forma de "uma utopia paradoxal no coração da querela das mulheres".

Alonso vê na obra de Labé, Le Débat de Folie et d'Amour (O Debate de Loucura e de Amor), uma querela de precedência, de desigualdade entre um homem e uma mulher que serve de pretexto para a discussão. Mas a autora diz também que, nesse texto, Labé "torna iguais e complementares os homens e as mulheres, com o fim de reconciliar aquilo que as pessoas se comprazem em opor", e vê nele "um texto feminista, emancipador das mulheres, socialmente e mentalmente, pela afirmação da complexidade e dos paradoxos da humanidade" (Alonso, 2013, p. 130-131).

Parece que não se tem ainda em Labé um conceito de igualdade entre os sexos, muito menos a afirmação da igualdade como um princípio universal. Mas, em carta de 1555, dirigida a uma amiga de nome Clémence, Labé (2013, p. 134) usa os termos “(ultra)passar ou igualar os homens" em ciência e virtude, para o que conclamava "as virtuosas senhoras a elevarem os seus espíritos para um pouco acima de suas rocas e fusos". A esse propósito, Viennot (2013, p. 133), referindo-se a Labé, fala em "vontade comum de apoiar a emergência das mulheres de letras, numa época em que seu acesso à cena literária, graças a toda a nova imprensa, suscitava muita irritação”. Em todo caso, teve-se que esperar pelo século XVII para se ter um conceito claro e universal de igualdade de gênero, que só viria com Marie de Gournay e Poulain de la Barre.

\section{Marie de Gournay, França, 1565-1645}

Decorridos cerca de dois séculos desde Christine de Pizan e setenta anos desde a obra citada de Labé, Marie de Gournay publica em Paris, em 1622, o pequeno tratado intitulado L'égalité des Hommes et des Femmes (A igualdade dos homens e das mulheres) - talvez a primeira publicação a utilizar já no título o termo "igualdade" para definir a relação entre os sexos. A autora é conhecida como Fille d'alliance (filha adotiva) do filósofo Montaigne, conhecido principalmente por seus Ensaios.

Educação \& Realidade, Porto Alegre, v. 46, n. 3, el13918, 2021. 
Querela das Mulheres, Igualdade e Direito à Educação

O uso frequente do termo lumière (luz), além de expressões como "atingir o meio dia desde o amanhecer", "a luz não conhece Ocidente", sugere a presença, em L'égalité, de lampejos de um iluminismo nascente, que, meio século mais tarde, se manifestaria com maior clareza e vigor em Poulain de la Barre.

Também em Légalité, a autora diz que, ao contrário de alguns defensores da causa das mulheres, que falam em superioridade destas em contraposição à superioridade masculina sustentada por outros, ela se contenta em igualar as mulheres aos homens e estranha que alguns, não satisfeitos em preferirem o sexo masculino, queiram ainda prender, de forma irrefragável, as mulheres à roca. Acrescenta com ironia que há homens que, "mais valentes que Hércules, que só desafiava doze monstros em doze combates, derrotam com uma só palavra metade do mundo [a metade feminina]". E desafia: "Quem irá, contudo, acreditar que aqueles que querem se elevar e fortificar com a fraqueza de outrem possam elevar-se ou fortificar-se com a sua própria força?". E quanto à instrução, diz que, se as mulheres atingem com menos frequência que os homens os níveis de excelência, admira que a falta de boa instrução e até a ocorrência de má instrução não as impeçam totalmente de lá chegar. (Gournay, 1978a, p. 61-63). E, minimizando a diferença entre os sexos no que respeita ao animal humano, a autora argumenta: "nada se parece mais com um gato na janela do que uma gata” (Gournay, 1978a, p. 70).

Referindo-se ao segundo tratado da autora: Le grief des dammes (A queixa das senhoras), de 1726, Schiff (1978, p. 89, nota 1) afirma que Gournay, desde a primeira linha, dá "livre curso às suas queixas contra os homens". Com efeito, as palavras de abertura do texto confirmam: "Feliz és tu, leitor, se não és do sexo ao qual se interditam todos os bens [...]. Feliz mais uma vez, tu que podes ser sábio sem crime, concedendote tua qualidade de homem tudo o que se proíbe às mulheres" (Gournay, 1978b, p. 89).

Em relação aos dois pequenos tratados de Gournay referidos acima, Schiff (1978, p. 47) sustenta que há que dar-lhes um lugar à parte na obra de Gournay, por se ver neles uma originalidade singular: primeiro, por ela ter "defendido, a todo custo, a mulher e as mulheres contra o injusto desdém dos homens"; segundo, por ter tratado com um calor persuasivo "um tema que não servia senão para gozação e que em seu tempo já havia suscitado incontáveis sátiras”. Referindo-se às querelas da época sobre a mulher, Schiff (1978, p. 48) diz que "havia rancores e simpatias, nada mais"; mas que Gournay tinha uma maneira totalmente diversa de proceder, podendo sua tese ser resumida no seguinte: "o homem e a mulher são criaturas equivalentes", no que ele identifica na autora "uma real independência de julgamento e uma grande coragem", especialmente se se considerar que "Marie não tinha, para se defender, nem mesmo a beleza que faz com que os homens perdoem por vezes às mulheres o fato de elas amarem o que eles não amam"; na realidade, nem as gatas de Gournay - Donzelle e Minette - estiveram a salvo das zombarias dos misóginos de plantão (Schiff, 1978, p. 37, 45 e 48). 
Mas, ressalvada a importância da contribuição de Marie de Gournay na luta pelos direitos das mulheres com base na igualdade, há que se notar que a ideia de igualdade entre os sexos não surgiu com a obra L'égalité em 1622. Com efeito, como utopia, já estivera presente pelo menos em Chistine de Pizan e em Louise Labé, como se mostrou antes.

Na avaliação de Fraisse (2012, p. 164, grifos meus), os escritos de Marie de Gournay poderiam estar indicando "o começo de uma transição: invocar, afirmar o equilíbrio, pronunciar o termo 'igualdade', fazer dele até o título de seu livro". Mas acrescenta: "Da ideia de igualdade, que ela [Marie] promove ao conceito propriamente [de igualdade], reconhecido e eficaz, percorre-se o caminho que, ao longo do Grande Século [XVII], leva a Poulain de la Barre" .

O período decorrido de Gournay e Poulain conheceu Descartes e seu dualismo, ou método dualista, que viria a tornar-se "subversivo para o pensamento sobre os sexos" (Fraisse, 2012, p. 164). O próprio Poulain (2011, p. 277) é categórico a respeito: "Não há nenhum [Método] que tenha falado com maior propriedade sobre preconceitos, nem que os tenha combatido com maior vigor".

\section{François Poulain de la Barre, França, 1647-1723 [1725?] Genebra}

Decorrido cerca de meio século desde o texto L'égalité de Marie de Gournay, tem-se, em 1673, a obra De l'égalité des deux sexes (Da igualdade dos dois sexos), do filósofo-teólogo cartesiano francês François Poulain de la Barre, nome que, como a maioria das/dos feministas, acabou sendo relegado ao esquecimento, só retornado à memória em pleno século XX, graças, em grande parte, à seguinte citação feita pela feminista Simone de Beauvoir em O segundo sexo, de 1949: “'Tudo o que os homens escreveram sobre as mulheres deve ser suspeito, porque eles são, a um tempo, juiz e parte', escreveu, no século XVII, Poulain de la Barre, feminista pouco conhecido" (Beauvoir, 1980, v.1, p. 15-16).

Já o primeiro parágrafo do Prefácio de De l'égalité surpreende pela maneira como o autor anuncia seu plano e intenção:

\footnotetext{
Não há nada mais delicado do que falar sobre as mulheres. Quando um homem fala em favor delas, as pessoas logo imaginam que é por galanteria ou por amor: é é muito provável que, em sua maior parte, ao julgar este discurso pelo Título, acreditarão logo que ele é efeito de um ou outro [de galanteria ou amor] e ficarão felizes em saber de verdade o motivo e a intenção [do autor] (Poulain De La Barre, 2011, p. 53).
}

Numa perspectiva cartesiana, Poulain afirma que "nós estamos cheios de preconceitos" e que "precisamos livrar-nos deles para obter conhecimentos claros e distintos". Anuncia, então, o preconceito de que se irá ocupar: "De todos os Preconceitos, não se encontrou nenhum mais próprio a esse objetivo do que aquele que comumente se tem sobre a desigualdade dos dois sexos" (Poulain de La Barre, 2011, p. 54). Pros- 
Querela das Mulheres, Igualdade e Direito à Educação

seguindo, Poulain diz que "Todo Mundo, tanto os que têm estudo como os que não têm, e mesmo as mulheres concordam em dizer que elas não têm parte nas Ciências e nos Empregos, porque elas não são capazes"; e que, para mudar esse entendimento, "é necessário fazer ver ao Vulgo [aos que não têm estudo]" "como as mulheres têm sido subjugadas e excluídas das Ciências e dos Empregos", e "mostrar que as provas dos Sábios são todas vãs" e que, ordinariamente, os defeitos de que as mulheres são acusadas "são imaginários ou de pouca importância" e "que eles vêm unicamente da educação que se lhes dá, produzindo nelas desvantagens consideráveis” (Poulain de La Barre, 2011, p. 54-55).

Na primeira parte de De l'égalité, o autor busca mostrar que “a opinião vulgar é um preconceito, e que, comparando-se desinteressadamente aquilo que se pode observar na conduta dos homens e mulheres, a pessoa fica obrigada a reconhecer entre os dois sexos uma igualdade completa"; na segunda parte, "faz ver porque os testemunhos que se pode aportar contra o sentimento de igualdade dos dois Sexos, extraídos dos Poetas, dos Oradores, dos Historiadores, dos Jurisconsultos, e dos Filósofos [na realidade, também dos médicos] são todos vãos e inúteis" (Poulain de La Barre, 2011, p. 59 e 89, grifos do autor). Mesmo que o autor não dê maior desenvolvimento ao tema da educação especificamente enquanto direito, há uma passagem interessante em De l'égalité, onde ele fala do direito à educação como direito à verdade, direito ao conhecimento (Poulain de La Barre, 2011, p. 111).

O tema da educação/instrução da mulher teve desenvolvimento prático-pedagógico nos diálogos mantidos em De l'éducation des dames (Da educação das senhoras), de 1674, onde Poulain trata dos meios de realizar a sua proposta, a saber: "que se instruam as mulheres com o mesmo cuidado com que se instruem os homens" e, como diz Sophie (dublê feminino, discípula tornada mestre) de Stasimaque (por sua vez dublê masculino de Poulain), "que aquele que tenha feito a Apologia das mulheres, realize também a sua instrução, para que elas tenham em relação a ele a obrigação de ter feito, para seu bem e sua glória, tudo o que um homem hábil é capaz de fazer" (Poulain de La Barre, 2011, p. 173 e 178-179).

No Prefácio a De l'égalité, Poulain imaginava que seu livro provocaria reação em muitos, e que aqueles cujos interesses e máximas fossem contrariados, não deixariam de gritar contra. Na realidade, isso não aconteceu, o que levou o autor a escrever um terceiro livro, intitulado De l'excellence des hommes (Da excelência dos homens), publicado em 1675, em que ele desempenha o papel de contraditor de si mesmo (Poulain de La Barre, 2011, p. 291-393).

A importância de Poulain de la Barre cresce, nos dias atuais, em virtude do peso que tem, em sua obra, o princípio da igualdade. Com efeito, diferentemente dos clássicos direitos de liberdade e igualdade formal, os direitos sociais fundamentais, hoje reconhecidos nacional e internacionalmente, entre os quais o da educação, "nasceram abraçados ao princípio da igualdade”, como já se referiu antes (Bonavides, 2017, p. 578). 
Nessa mesma linha, há que se destacar a obra François Poulain de la Barre and the invention of modern equality (François Poulain de la Barre e a invenção da igualdade moderna), em que o holandês Siep Stuurman $(2004$, p. 1) vê, no ex-estudante de Teologia da Sorbonne (Poulain), uma das mais remarcáveis ausências na historiografia do primeiro iluminismo; justamente aquele que, no início dos anos 1670, "formulou uma filosofia social Cartesiana, feminista e radicalmente igualitária" e que "publicou três tratados sobre a igualdade entre mulheres e homens que, com toda probabilidade, são os textos mais radicalmente igualitários publicados na Europa antes da Revolução Francesa".

Na obra citada, o autor vai além, sustentando a seguinte tese:

O significado histórico de Poulain está no fato de ele ter formulado uma filosofia igualitária sistemática, na qual, pela primeira vez, a ideia da igualdade natural de todos os seres humanos possuidores de razão é aplicada a todos os tipos de relações sociais. Poulain é talvez o único pensador do século XVII que formulou um conceito verdadeiramente universal de igualdade (Stuurman, 2004, p. 296, grifo do autor).

Stuurman (2004, p. 297) destaca que essa filosofia social cartesiana igualitária de Poulain é reconhecida geralmente como um marco na história do feminismo, para em seguida dizer que pretendeu mostrar, em seu livro, que essa mesma filosofia é um marco também em outra história - a da criação ou invenção do Iluminismo, dimensões "tratadas pela primeira vez junto, num argumento sistemático". Ainda segundo o autor, isso se torna claro quando se olha para além do feminismo e cartesianismo, considerando também outros contextos como "autoridade e lei natural, teorias da educação, antropologia, história e finalmente religião e teologia", o que leva o autor a dizer que Poulain, produto de seu tempo, "explora os limites do pensável na Europa do final do século XVII".

Mas Marie de Gournay e Poulain de la Barre não foram os únicos a lutar pela igualdade dos sexos. Aliás, referindo-se à longa querela das mulheres, D. Haase-Dubosc (2015) diz que, no período da República das Letras, essa querela acabou tornando-se uma guerra:

[...] quando uma autora manifesta a sua presença literária e feminina sobre a grande cena discursiva da Querela, trata-se de Marie de Gournay ou das Preciosas, de Germaine Necker ou de George Sande ${ }^{10}$, para não nomear mais que as mais conhecidas dos franceses, a crítica literária que se dirige ostensivamente às obras desta, sai do campo circunscrito da literatura para se derramar sobre a pessoa, sobre o seu próprio corpo, [que passa a ser] tratado como feio, mal lavado, velho horror lúbrico, designado sob traços de diversos animais [...]. É então que os argumentos que demonstram a inferioridade das mulheres e provam a impossibilidade da igualdade dos sexos transbordam a sua moldura literária e passam a alimentar não só uma Querela, mas uma Guerra da qual nem a autora melhor 
armada sai ilesa (Haase-Dubosc, 2015, p. 225, grifos da autora).

Dois séculos depois de Poulain de la Barre, o filósofo do feminismo do século XIX, John Stuart Mill, seria taxativo na afirmação de que "a subordinação legal de um sexo ao outro" deveria ser substituída "por um princípio de igualdade perfeita, sem qualquer poder ou privilégio para um lado ou para o outro" (Mill, 2006, p. 15).

\section{De um século de feminismo de maré baixa à Revolução Francesa}

Segundo Groult (2010, p. 45), a Poulain de la Barre seguiu-se um século de "feminismo de maré baixa" Boileau, La Rochefoucauld, Buffon, Fénelon, Saint-Evremond, Racine, La Bruyère, "retomam, para falar das mulheres, o tom paternalista ou desdenhoso dos misóginos tradicionais e recorrem a uma ironia feroz face a qualquer veleidade de independência e de cultura". Em relação ao que aqui interessa, vale lembrar uma das lições contidas em Escola de mulheres $^{12}$, de 1662, sobre os deveres da mulher casada:

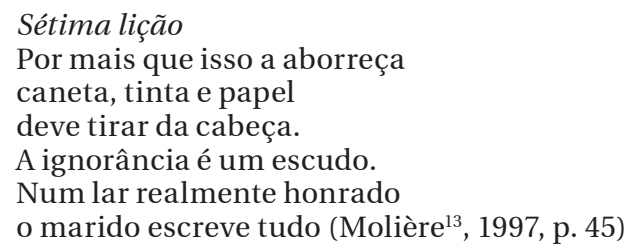

Na lista acima, Groult (2010, p. 51) deixou de incluir Rousseau, para, adiante, defini-lo como o "brilhante líder do antifeminismo do século XVIII, que vai influenciar a maior parte dos revolucionários, os mais ativos em todo o caso, Robespierre à frente".

Decorrido esse século de "feminismo de maré baixa", chega-se ao tempo da Revolução Francesa (1789). De Christine de Pisan até ali não se avançara muito quanto ao direito à educação, se pensado este em termos de conquista efetiva, ou, para usar expressão de Bobbio (2004, p. 15), de "direito que se tem". Basta lembrar que a educação não aparece na Declaração dos Direitos do Homem e do Cidadão de 1789, tendo sido lembrada, mas nunca como direito, em apenas três dos 48 Projetos de Declaração reunidos em dossier por Rials (1988, p. 475-749) em sua obra La declaration des droits de l'homme et du citoyen. A Constituição Francesa de 1791 também não contém nenhuma afirmação de direito à educação. Diz apenas que

será criada e organizada uma Instituição pública comum a todos os cidadãos, gratuita no que concerne às partes de ensino indispensáveis para todos os homens e cujos estabelecimentos serão distribuídos gradualmente, levandose em conta a divisão do reino (France, 1791). 
Mas o direito à educação avançara, sim, se, recorrendo-se mais uma vez a Bobbio (2004, op. 15), a educação é pensada em termos de "direito que se gostaria de ter".

O período revolucionário de que se está falando foi de grande importância nessa luta por educação: primeiro, pelo lugar de destaque que o tema da instrução pública teve no período revolucionário; segundo, pela expressão e repercussão internacional que tiveram as obras de três feministas que, em Paris e Londres, se posicionaram em defesa da instrução pública no acontecer da Revolução, como se verá a seguir.

\section{Na França, nos anos da Revolução: Marquês de Condorcet, França, 1743-1794}

Jean-Antoine-Nicolas de Caritat, marquês de Condorcet, é considerado o teórico da escola republicana. No que se refere ao tema aqui abordado, a primeira obra do autor a considerar é Sobre a admissão das mulheres ao direito de cidadania, publicada originalmente em 1781 e reeditada em 1789. É interessante que, quase uma década antes da Declaração dos direitos do homem e do cidadão, Condorcet houvesse reivindicado para as mulheres o direito de cidadania, direito que a Declaração, assim como as Constituições francesas do início dos anos 1790, não contemplariam. Condorcet (1991, p. 45) inicia o texto dizendo que "O hábito pode familiarizar as pessoas com a violação dos direitos naturais" e exemplifica questionando: "não violaram todos o princípio da igualdade dos direitos, privando tranquilamente a metade do gênero humano daquele de concorrer para a formação das leis, excluindo as mulheres do direito de cidadania?" À objeção de que as mulheres não tinham propriamente o sentimento da justiça e que elas obedeciam mais ao sentimento do que à consciência, o autor responde dizendo que, mesmo se verdadeira, essa observação não provaria nada, porque “[...] não é a natureza, é a educação, é a existência social que causa essa diferença. Nem uma nem outra acostumaram a mulher ao que é justo, mas sim ao que é honesto" (Condorcet, 1991, p. 48). Note-se a ênfase atribuída pelo autor à educação. Note-se ainda que, no referido artigo, o autor se refere não a um direito político específico, como o do voto, mas ao conjunto dos direitos do homem, que ele defende que sejam também das mulheres: "Ora, os direitos dos homens resultam do fato de que são seres sensíveis, suscetíveis de adquirir ideias morais e de raciocinar sobre essas ideias. Assim, tendo as mulheres essas mesmas qualidades, têm, necessariamente, direitos iguais" (Condorcet, 1991, p. 45-46).

Em suas Réflexions sur l'esclavage des Nègres (Reflexões sobre a escravidão dos negros), texto igualmente publicado em 1781 e reeditado às vésperas da Revolução, Condorcet defende também a libertação dos escravos. O Autor começa dizendo: "Embora eu não seja da mesma cor de vocês, eu tenho considerado vocês sempre como meus irmãos. A natureza formou vocês para terem o mesmo espírito, a mesma razão, as mesmas virtudes que os Brancos" (Condorcet, 1781, p. 5) Diz a seguir que, em seu texto, não iria empregar a eloquência, mas a razão; que 
Querela das Mulheres, Igualdade e Direito à Educação

iria falar "não dos interesses do comércio, mas das leis da justiça"; e que tinha consciência de que os tiranos deles o reprovariam por só dizer coisas comuns e por não ter mais que ideias quiméricas. No que, aliás o autor concordava, porque, dizia ele, "com efeito, nada é mais comum do que as máximas da humanidade e da justiça" e "nada é mais quimérico do que propor aos homens conformarem sua conduta [a essas máximas]" (Condorcet, 1781, p. 5-6)

Antes de tratar da concepção de Condorcet sobre a educação como direito, vale lembrar as palavras de Bobbio:

\begin{abstract}
Todas as declarações recentes dos direitos do homem compreendem, além dos direitos individuais tradicionais, que consistem em liberdades, também os chamados direitos sociais, que consistem em poderes. Os primeiros exigem da parte dos outros (incluídos aqui os órgãos públicos) obrigações puramente negativas, que implicam a abstenção de determinados comportamentos; os segundos só podem ser realizados se for imposto a outros (incluídos aqui os órgãos públicos), um certo número de obrigações positivas (Bobbio, 2004, p. 21)
\end{abstract}

E adiante $o$ autor sentencia: "A figura do direito tem como correlato a figura da obrigação" (Bobbio, 2004, p. 74)

$\mathrm{O}$ que se quer mostrar agora é que se encontram em Condorcet todos esses elementos que seriam destacados por Bobbio dois séculos mais tarde: a noção de direitos sociais, de poderes (direitos), tendo como correlato obrigações positivas de parte dos órgãos públicos. Em 1791 o referido autor publicava cinco artigos, depois reunidos na obra Cinco memórias sobre a instrução pública, onde defende a instrução pública como "meio de tornar real a igualdade de direitos", como "dever da sociedade", como "meio de aperfeiçoar a espécie humana"..., instrução esta que, segundo ele, deveria ser "a mesma para as mulheres e os homens" (Condorcet, 2008, p. 17; 25; 57).

Já no início da "Primeira memória", onde fala da natureza e objeto da instrução pública, o autor é explícito e enfático na afirmação da instrução pública como dever da sociedade e direito de todos: "A sociedade deve ao povo uma instrução pública", e isto por se tratar do "meio de tornar real a igualdade de direitos" (Condorcet, 2008, p. 17, grifo meu). Por sua vez, a não oferta de instrução pública devida ao povo coloca o Estado na condição de devedor.

No que se refere às mulheres, o autor é explícito quanto à igualdade de direito à instrução: "É necessário que as mulheres compartilhem a instrução comum dada aos homens”. Quanto a isto, Badinter (1991, p. 18) observa que Condorcet tenta habilmente convencer os leitores "utilizando argumentos altruístas, que subordinam a instrução feminina ao bem da criança, do esposo e da família", e que "só em último lugar evoca o direito das mulheres à instrução pública". Mas, como se tem na primeira das Cinco memórias, o autor sustenta que a instrução pública "é um dever da sociedade para com os cidadãos"; que "deve ser a mesma para as mulheres e os homens"; que "as mulheres têm os mesmos direitos 
que os homens"; que elas têm, por isso, "o direito de obter as mesmas facilidades para adquirir as luzes, que podem lhes dar os meios de exercer realmente tais direitos, com uma mesma independência e numa mesma extensão", devendo por isso a instrução "ser dada em comum" (Condorcet, 2008, p. 17; 57; 60-61, grifos meus).

É claro que, repetindo Bobbio (2004, p. 15), não se trata aqui (em Concorcet) de um direito que se tem, mas apenas de um direito que se gostaria de ter - que se quer ver reconhecido.

Concluindo, pode-se dizer que Condorcet, o teórico da escola republicana, foi também a expressão teórica máxima em defesa dos direitos da mulher, com destaque para o direito à educação, no período da Revolução Francesa, e que associou a libertação das populações negras escravizadas à libertação das mulheres.

No Relatório e projeto de decreto sobre a organização da instrução pública, que foram apresentados à Assembleia Nacional em nome do Comitê de Instrução Púbica em 20 e 21 de abril de 1792, Condorcet, ao definir a primeira finalidade da instrução nacional, associa ao princípio da igualdade aquele da universalidade:

\begin{abstract}
Nós pensamos que no plano da organização geral [da instrução pública] nosso primeiro cuidado deveria ser de tornar, por um lado, a educação tão igual quanto universal; e, de outro, tão completa quanto as circunstâncias possam permitir; [...] Assim, a instrução deve ser universal, melhor dizendo, deve estender-se a todos os cidadãos (Condorcet, 2010, 23-24).
\end{abstract}

E concluindo esta parte, há que ressaltar que o autor, quando usa o termo igualdade, entende-o não como igualdade formal, mas como igualdade real (Condorcet, 1993, p. 17 e 185).

\title{
Olympe de Gouges, França, 1748-1793
}

Olympe de Gouges, pseudônimo de Marie Gouze, nasceu em 1748, em Montauban, no sudoeste da França. Considerava-se filha ilegítima de um senhor de Montauban, sem nunca ter sido reconhecida como tal, o que a levou a tornar-se defensora apaixonada dos direitos das crianças ilegítimas. Casou-se bem jovem, tendo um filho em 1765 e enviuvando em seguida. Em 1770 mudou-se para Paris. Tornou-se conhecida como dramaturga, ativista política, defensora dos direitos da mulher e abolicionista.

Em 17 de abril de 2014, a Prefeitura de Montauban rendeu-lhe homenagem por ocasião da cerimônia de entrega de diplomas aos nomeados e promovidos na Ordem das Palmas Acadêmicas, ressaltando-se, na ocasião, que Olympe travou muitas lutas até 1793 , ano em que foi guilhotinada: "Combates, com certeza, em favor dos direitos da mulher, mas também em favor dos negros. É propriamente com esse tema que ela entra na literatura. [...] Pela primeira vez no teatro ela escolhe como personagens principais escravos negros [...].” (André-Acquier, 2014, p. 1) 
Querela das Mulheres, Igualdade e Direito à Educação

E note-se o que diz Perrot (2014, p. 34) a propósito do envolvimento de Olympe com o teatro: "Era ainda mais difícil tornar-se mulher de teatro do que mulher de letras", especialmente se se considera que a autora "colocava em cena uma sociedade de plantadores escravagistas, desumana e injusta”.

Quanto à escrita, Perrot (2014, p. 17) observa que Olympe "deplorava não dominar a arte da redação"; que "a escrita foi para ela principalmente instrumental, um grito protestatório, veemente"; que ela tinha "o talento do manifesto". Talento que se expressou plenamente e a consagrou em 1791, na Déclaration des droits de la femme e de la citoyen$n e$ (Declaração dos direitos da mulher e da cidadã), em que ela afrontou o machismo dominante entre os revolucionários franceses. Ainda segundo Perrot (2014, p. 17), foi nessa Déclaration que a perenizou, que Olympe "alcançou os cumes da concisão percuciente", porquanto "Tornar-se célebre por um único texto é uma grande arte”.

Com efeito, enquanto a Declaração de 1789 era totalmente omissa quanto a afirmar qualquer direito humano para as mulheres (Rials, 1988), a Declaração de Olympe de Gouges, de 1791 (1993, art. I e postâmbulo), seria explícita e contundente, começando por afirmar que "I. A mulher nasce livre e permanece igual ao homem em direitos", e que, por isso, "II. As distinções sociais não podem fundar-se a não ser na utilidade comum", para, ao final, sentenciar: "[...] e já que se trata, nesse momento, de uma educação nacional, vejamos se os nossos sábios Legisladores irão pensar judiciosamente sobre a educação das mulheres" (Gouges, 1993, artigos I e II e póstâmbulo).

Da mesma forma, na Déclaration de Olympe os direitos da mulher estendem-se também ao campo da política e ao mundo do trabalho:

VI. A lei deve ser a expressão da vontade geral; todas as Cidadãs e Cidadãos devem concorrer pessoalmente, ou através de seus representantes, para a sua formação; ela deve ser a mesma para todos: todas as Cidadãs e todos os Cidadãos, sendo iguais a seus olhos, devem ser igualmente admissíveis a todas as dignidades, lugares e empregos públicos, segundo suas capacidades, e sem outras distincões que não sejam suas virtudes e seus talentos (Gouges, 1993, art. VI).

Mas a luta pelo voto universal não existia ainda e só se tornaria uma reivindicação após 1840, colocando-se então "no coração da agitação política" (Perrot, 2014, p. 86).

Nos artigos VII e IX de sua Declaração, referindo-se à legislação penal, Gouges (1993) diz que toda mulher, sem exceção, está sujeita à lei, podendo ser acusada, presa e detida nos casos determinados pela lei, e que, se declarada culpada, a lei será exercida sobre ela com todo o rigor.

Mas há parte de um artigo da Declaração de Olympe, que os misóginos da Convenção voltaram contra ela. Com efeito, dos dois direitos reivindicados para a mulher no artigo X ("a mulher tem o direito de subir ao cadafalso; ela deve ter também o direito de subir à tribuna”), somente o primeiro lhe foi reconhecido e prontamente aplicado em 1793, 
com recurso, inclusive, à recente invenção de Guillotin - a guilhotina. Talvez Olympe não pudesse antever que, dois séculos mais tarde, se escreveria que "as mulheres tinham o direito de subir à guilhotina, mas não à tribuna" (Badinter, 1991, p. 41).

Com efeito, se, de um lado, como observa Badinter (1991), a Revolução Francesa melhorou sensivelmente o estatuto jurídico das mulheres entre 1789 e final de 1793, como na Constituição de 1791, que instaurou o casamento civil, com reconhecimento das mulheres como sujeitos de direito privado, de outro, no tocante à participação política, no final de 1793 a Convenção interditava-lhes não só a tribuna, mas também os clubes e sociedades populares femininas.

Talvez os convencionais tenham encontrado motivação para tais interdições na "ousadia" de Lisístrata e Corifeia e no temor e revolta de Corifeu, personagens da peça Lisístrata: a greve do sexo, de Aristófanes, na Grécia antiga, em 411 a.C., mais de 2 milênios antes da Revolução Francesa:

Lisístrata - E diga que venham todos, para tratamento igual. Diga-lhes que a lei, agora, também é feminina. Se isto não é melhor, pelo menos será bem mais barato.

$[\ldots]$

Corifeu - Porque; atentem bem. É um crime e uma vergonha deixar as mulheres fazerem arengas aos cidadãos, ensinando-lhes que isto é patriótico, aquilo é ilegal, isto é cívico, aquilo imoral. Elas chegaram à ousadia de pregar união com os espartanos [...]. Mas eu: eu não me submeterei! Pra começar a reação vou me colocar agora mesmo na praça, como estátua, no monumento de Hecateia. [...] E quando essa estúpida passar vou lhe mijar em cima. Corifeia-Pode ser. Mas eu não te aconselharia a fazer isto, porque, depois, nem tua própria mãe vai te reconhecer.

$[\ldots]$

Corifeia - Não temerei as ameaças masculinas [...]. Podem fazer decretos e mais decretos condenando as mulheres, ó criaturas abomináveis, que nós não cederemos [...] (Aristófanes, 2003, p. 66-69).

\section{Mary Wollstonecraft, Inglaterra, 1759-1797}

Mesmo que se tenha dito que este trabalho foca o tema da querela das mulheres e do direito à educação na França, no período de 1399 à Revolução Francesa, decidiu-se tratar aqui, mesmo que muito brevemente, da feminista inglesa Mary Wollstonecraft por vários motivos: primeiro, a relação da autora inglesa com a querela das mulheres na França; segundo, o fato de sua obra Vindication of the Rights of Woman (Reivindicação dos direitos da mulher), ter sido publicada em 1792 "em resposta à Constituição Francesa de 1791, que não incluía as mulheres na categoria de cidadãs" (Moraes, 2016, p. 7); terceiro, a sua relação com a chegada ao Brasil da luta das mulheres por direitos, o que se deu em 1832, com a publicação de Direitos das mulheres e injustiça dos homens, que a própria autora brasileira Nísia Floresta Brasileira Augusta definiu 
Querela das Mulheres, Igualdade e Direito à Educação

como "Tradução livre do original Vindication of the Rights of Woman, de Mary Wollstonecraft" (Floresta, 1989, p. 1).

Em 1792, do outro lado do Canal da Mancha, a inglesa Mary Wollstonecraft publica o livro Vindication of the rights of women, recentemente traduzido e publicado no Brasil sob o título de Reivindicação dos direitos da mulher (2016), obra que a autora dedica a Talleyrand-Perigord, antigo bispo de Autun e político ativo durante a Revolução Francesa. Aliás, note-se que a autora se encontrava em Paris quando da tomada da Bastilha em 1789, tendo-se possivelmente encontrado com Olympe de Gouges e o marquês de Condorcet.

A autora critica Talleyrand-Perigord por entender que ele havia tratado do tema dos direitos da mulher de maneira por demais superficial e solicita-lhe que se digne avaliar o que ela está propondo a respeito dos direitos da mulher e da instrução pública (Wollstonecraft, 2016). Declara também que seu principal argumento nessa "luta pelos direitos da mulher" baseia-se neste simples princípio: "se a mulher não for preparada pela educação para se tornar a companheira do homem, ela interromperá o progresso do conhecimento e da virtude, pois a verdade deve ser comum a todos ou será ineficaz no que diz respeito a sua influência na conduta geral"; e numa crítica à Constituição Francesa de 1791, conclui dirigindo-se a Talleyrand-Perigord: "quando sua Constituição for revisada, pode ser que os direitos da Mulher sejam respeitados" (Wollstonecraft, 2016, p. 18 e 21).

No capítulo dedicado à educação nacional, a autora defende não só uma educação escolar para as mulheres igual à dos homens, mas também a coeducação: "para que ambos os sexos se aperfeiçoem, é necessário, não apenas na privacidade das famílias, mas também nas escolas públicas, que eles sejam educados juntos" (Wollstonecraft, 2016, p. 214).

Em sua Introdução à edição da Penguin English Library, Kramnick (1983, p. 38, 52 e 53) diz que Vindication foi construída "sobre o pressuposto da igualdade dos sexos", que é "uma refutação das teorias de Rousseau sobre as mulheres", e que a Sophie de Rousseau é a "antítese da mulher racional de Wollstonecraft". Pode-se acrescentar que, em contraposição à tese de Rousseau, de uma educação de dominação para Emílio e outra de subordinação para Sofia, a autora de Vindication defende como direito uma educação igual para homens e mulheres. Poder-se-ia ainda dizer que a Sophie de Rousseau é a antípoda da Sophie de Poulain de la Barre referida antes.

Há que notar ainda que, assim como o marquês de Condorcet e Olympe de Gouges em Paris, também Mary Wollstonecraft em Londres associa a causa da libertação dos escravos à causa dos direitos da mulher. A esse respeito, vale reproduzir aqui o que diz a autora do prefácio à tradução brasileira da obra de Wollstonecraft:

O feminismo iluminista de Mary Wollstonecraft e Olympe de Gouges compartilha da mesma crença na importância da educação e na universalidade de direitos, fazendo eco 
a Condorcet. É um feminismo que se opõe à escravidão dos africanos e indígenas e à escravidão doméstica. Ambas viveram tempos históricos em que a mulher estava excluída da educação formal, das universidades e das possibilidades de uma carreira de nível superior. [...]

Em alguns pontos, o texto [de Condorcet] é ainda mais radical, do que Reivindicação, pois propugna não somente a igualdade dos direitos da mulher à educação, mas também ao voto e à propriedade privada, aos cargos públicos, ao reconhecimento dos filhos nascidos fora do casamento e à herança (Moraes, 2016, p. 10).

Mesmo na França, decorrido quase um século desde a Revolução Francesa, em carta de 8 de junho de 1872 a Léon Richer, cofundador com Marguérite Durand, em 1869, da Associação para os Direitos das Mulheres, Victor Hugo (1872, p. 1) escrevia: "É doloroso dizer: na civilização atual, há uma escrava. A lei tem eufemismos: o que eu chamo uma escrava, ela chama uma menor; essa menor segundo a lei, essa escrava segundo a realidade, é a mulher". E adiante: "Na questão da educação, como na questão da repressão, [...] na questão do ensino obrigatório, gratuito e laico, na questão da mulher, na questão da criança, é tempo de os governantes se darem conta". Na realidade, a França teria que esperar pelo início da década de 1880, para ver estabelecida a escolarização obrigatória, gratuita e laica para ambos os sexos. Mas, quanto ao direito de voto, as mulheres francesas só o obteriam em 1945.

Antes de concluir, há que observar que nenhum dos três autores Condorcet, Gouges, e Wollstonecraft - era profissional da área do direito. Não se poderia, pois, avaliar seu pensamento sobre direito à educação em termos do vocabulário técnico dessa área do conhecimento. Se a luta por educação também para as mulheres, e igual à proporcionada aos homens, raramente era entendida como luta por um "direito" (direito à educação), não se pode esquecer que essa luta era travada em nome da igualdade e, no último quartel do século XVIII, em nome do princípio da igualdade, consagrado tanto na Declaração de Independência dos Estados Unidos em 1776 e em Declarações de Direitos de vários Estados americanos individualmente, quanto na Declaração dos Direitos do Homem e do Cidadão na Revolução Francesa em 1789.

\section{Conclusão}

As autoras e os autores examinados neste trabalho raramente têm falado explicitamente em direito à educação. Não se falava ainda em direitos sociais. No entanto, um ponto importante pode ser dado como estabelecido: em todo o período examinado, de 1399 até final do século XVIII, a educação tem ocupado lugar central na querela das mulheres dentro do conjunto de direitos reivindicados. Em relação especificamente à questão levantada no início, o estudo realizado sugere fortemente que essa multissecular querela das mulheres e os temas ali discutidos, particularmente o da igualdade, contribuíram, sim, para a construção daquilo que hoje leva o nome de direito à educação, mas 
Querela das Mulheres, Igualdade e Direito à Educação

tendo-se que admitir com Bobbio (2004) que, até início do século XX, tratava-se de um direito que se gostaria de ter, não ainda de um direito que se tem.

Na verdade, o direito da mulher à educação foi um processo que levou séculos para conseguir reconhecimento na legislação e ir concretizando-se em diferentes medidas, nos diferentes países e regiões, para diferentes classes, sexos, raças..., e que desde o início se buscou fundamentar na igualdade: primeiro, na igualdade como ideia ou utopia (Christine de Pizan, final do século XIV e primeiro terço do século XV); depois, no século XVII, na igualdade como conceito (Marie de Gournay e Poulain de la Barre) e como princípio (Poulain de la Barre); por fim, no final do século XVIII, na igualdade fundamentando a educação como objeto de política pública (Condorcet, Olympe de Gouges e Mary Wollstonecraft).

Levando-se em conta os preconceitos generalizados em voga contra as mulheres no final do século XIV e no século XV, há que reter pelo menos cinco pontos importantes em relação à protofeminista Christine de Pizan: primeiro, o interesse pessoal de Christine pelo estudo e pela escrita (autoria); segundo, o apoio recebido do pai, do marido e inclusive do rei Carlos V e de membros da corte; terceiro, o privilegiado acesso à biblioteca real; quarto, o falar como mulher e como representante do universo feminino; quinto, o haver feito da educação uma causa de todo o sexo feminino.

Fraisse (2012) estima que, dois séculos depois de Christine, Marie de Gournay, ao promover a ideia de igualdade a conceito propriamente de igualdade, reconhecido e eficaz, permitiu que se percorresse o caminho que, ao longo do Grande Século [XVII], levou a Poulain de La Barre, feminista tão importante entre os poucos homens feministas nesse século, quanto relegado por séculos ao esquecimento.

Outro ponto fundamental a registrar é que a querela das mulheres, em sua luta por direitos ao tempo da Revolução Francesa, se fez acompanhar de uma dimensão verdadeiramente universalista. Com efeito, já em 1781, 8 anos antes da Revolução, Condorcet defendia tais direitos para todos os seres humanos. Olympe de Gouges, por sua vez, defendia a extensão de tais direitos aos negros, e Mary Wollstonecraft, aos negros e índios.

Finalmente, há que registrar que o repentino agravamento das condições de saúde desde o início de 2018 levou o autor deste artigo a solicitar ao CNPq antecipação do término do projeto pesquisa, término que estava previsto para fevereiro de 2020. Esta situação impediu a realização de um segundo trabalho, este sobre como a luta das mulheres por direitos chegou ao Brasil e como aqui se desenvolveu, tomando-se como ponto de partida a obra Direitos das mulheres e injustiça dos homens, publicada em 1832, pela jovem potiguar Nísia Floresta Brasileira Augusta (22 anos), na cidade de Recife, com segunda edição em Porto Alegre logo no ano seguinte ${ }^{14}$.

Recebido em 20 de abril de 2021

Aprovado em 11 de maio de 2021 


\section{Notas}

1 Trabalho desenvolvido dentro de projeto de pesquisa apoiado pelo Conselho Nacional de Desenvolvimento Científico e Tecnológico-CNPq, para o período de março/2015 a fevereiro/2020 e, por igual período, pela Universidade Federal do Rio Grande do Sul/Faculdade de Educação e Programa de Pós-Graduação em Educação. Na realidade, por problema de saúde do pesquisador, o término do projeto foi antecipado para maio de 2019.

2 São do autor deste artigo as traduções do inglês referentes Stuurman (2004), Kramnick (1983), Larsen e United States (1776).

3 São do autor deste artigo as traduções do francês referentes a Pellegrin (2011), assim como as de Alonso (2013), André-Acquier (2014), Bolufer e Cabré (2015), Condorcet (1781), Dor (2015), Fraisse (2012), France (1791), Gouges (1993 e 1786), Gournay (1910a; 1910b), Groult (2010), Haase-Dubosc (2015), Henneau (2015), Hugo (1872), Labé (2013), La Déclaration... (1988), Noack (1993), Paupert (2013), Perrot (2014), Pizan (1399), Poulain de la Barre (2011), Rials (1988), Scriff (1978), Swift (2013), Viennot (2012 e 2013) .

4 De maneira semelhante, pelos limites impostos à extensão do texto, foi necessário abandonar a ideia inicial de estender o estudo à(s) fontes(s) e ao processo de entrada da querela no Brasil no final do primeiro quartel do século XIX. Sobre isto, pode-se consultar a obra Nísia Floresta, a primeira feminista do Brasil (Duarte, 2005).

5 O termo feminismo nasceria por volta de 1830, da pena do socialista utópico Charles Fourier, "inesgotável inventor de neologismos", mas só entraria na linguagem corrente a partir de um Congresso de Direitos da Mulher, realizado em Paris, em 1892, sob a presidência de Marguérite Durand (Groult, 2010, p. 18-19).

6 A Épistre (Carta) constituía um estilo literário.

7 Citação de La cité des dames, de Christine de Pizan (1996, I, p. 27).

8 Pelo final dos anos 1430, contrapondo-se à misoginia reinante, o nobre galego Juan Rodrigues de la Cámara, secretário de um cardeal a serviço do rei João II de Castela, respondendo a demanda de Maria de Aragão, rainha de Castela (1403-1445), lista nada menos do que quarenta motivos para se acreditar na superioridade das mulheres, entre os quais, o fato de a mulher ter sido criada após todas as outras coisas e o de ter sido criada de carne purificada (da costela de Adão). (Sobre Cámara e outros autores e autoras que escreveram sobre a superioridade das mulheres, cfr. M. Bolufer e M. Cabré, 2015, p. 32-67).

9 O Grande Século foi marcado por inúmeras outras presenças importantes, em vários países da Europa, em defesa dos direitos das mulheres. Marie de Gournay, por exemplo, correspondeu-se com Anna Maria van Schurman (16071678), calvinista, primeira estudante universitária na Europa (Universidade de Utrecht, na Holanda), formada em direito, com domínio do latim (aprendido com o pai), grego, hebraico e várias outras línguas, correspondente e admiradora de Gournay, defensora do acesso da mulher à educação superior, que se notabilizou por sua tese escrita em latim - Dissertatio de ingenii muliebris ad doctrinam et meliores litteras aptitudine, traduzida para várias línguas, como para o inglês, em 1659, sob o título de The learned maid (A jovem instruída) (Larsen, 2008). 
Querela das Mulheres, Igualdade e Direito à Educação

10 Pseudônimo de Amantine Lucile Aurore Dupin.

11 Esse século de "feminismo de maré baixa" de que fala Groult coincide praticamente com o período conhecido como República das Letras, que teve início no final do século XVII e se estendeu até fins do século XVIII.

12 Tradução de Millôr Fernandes.

13 "Não é que Molière seja inimigo das mulheres: ataca vivamente os casamentos impostos, reivindica para as jovens o direito à liberdade sentimental e para a esposa o respeito e a independência" (Beauvoir, v. 1, 1980, p. 139)

14 Alceu Ravanello Ferraro, autor deste artigo, faleceu em 2019.

\section{Referências}

ALONSO, Béatrice. Le débat de Folies et d'Amour de Louise Labé (1556), une utopie paradoxale au coeur de na Querelle des Femmes. In: DUBOIS-NAYT, Armed; DUFOURNAUD, Nicole; PAUPERT, Anne (Dir.). Revisiter la 'Querelle des femmes'. Discours sur l'égalité/inégalité des sexes, de 1400 à 1600. Saint-Etienne: Université de Saint-Etienne, 2013. P. 121-131.

ANDRÉ-ACQUIER, Geneviève (Org.). Olympe de Gouges et la question de l'esclavage des noirs. Hommage rendu à Olympe de Gouges à l'occasion de la cérémonie de remise de diplômes aux nommés et promus dans l'ordre des Palmes académiques, le 17 avril 2014, à la préfecture de Montauban. Montauban, 2014. Disponível em: <http://web.ac-toulouse.fr/automne_modules_files/ pDocs/public/r26109_61_olympe_de_gouges_et_la_question_de_lesclavage_ des_noirs.pdf>. Acesso em: 7 set. 2017.

ARISTÓFANES. Lisístrata: a greve do sexo. Tradução de Millôr Fernandes. Porto Alegre: L\&PM, 2003.

BADINTER, Elisabeth. Prefácio. In: BADINTER, Elisabeth (Org.). Palavras de homens (1790-1793): Condorcet, Prudhomme, Guyomar et al. Tradução de Maria Helena Franco Martins. Rio de Janeiro: Nova Fronteira, 1991. P. 7-41.

BEAUVOIR, Simone de. O segundo sexo. 1. Fatos e mitos. 6. ed. Rio de Janeiro: Nova Fronteira, 1980.

BOBBIO, Norberto. A era dos direitos. Tradução de Carlos Nelson Coutinho. Rio de Janeiro: Elsevier, 2004.

BOLUFER, Mónica; CABRÉ, Montserrat. La querele des femmes en Espagne: Bilan sur l'histoire d'un debat (1400-1800). In: DUBOIS-NAYT, Armed; HENNEAU, Marie-Élisabeth; KULESSA, Retraud von (Dir.). Revisiter la Querelle des femmes. Discours sur l'égalité/inégalité des sexes en Europe, de 1400 aux lendemains de la Révolution. Saint-Etienne: Université de Saint-Etienne, 2015. P. 32-67.

BONAVIDES, Paulo. Curso de Direito Constitucional. 32. ed. atualizada. São Paulo: Malheiros, 2017.

CALADO, Luciana Eleonora de Freitas. A Cidade das Damas. A construção da memória feminina no imaginário utópico de Christine de Pizan. 2006. Tese (Doutorado em Letras) - Programa de Pós-Graduação em Letras, Universidade Federal de Pernambuco, Recife, 2006. Disponível em: <https://repositorio.ufpe. br/handle/123456789/7590>. Acesso em: 2 set. 2017.

COMPARATO, Fábio Konder. A afirmação histórica dos direitos humanos. 6 . ed. São Paulo: Saraiva, 2008. 
CONDORCET, Jean-Antoine-Nicolas de Caritat, marquis de. Réflexions sur l'esclavage des nègres. 1781. Neufchatel: La Société Typographique, 1781. Disponível em: <http://classiques.uqac.ca/classiques/condorcet/reflexions_esclavage_negres/condorcet_reflexions_esclavage.pdf>. Acesso em: 05 dez. 2017.

CONDORCET, Jean-Antoine-Nicolas de Caritat, marquis de. Sobre a admissão das mulheres ao direito de cidadania. In: BADINTER, Elisabetrh (Org.). Palavras de homens (1790-1793): Condorcet, Prudhomme, Guyomar... [et al.]. Tradução de Maria Helena Franco Martins. Rio de Janeiro: Nova Fronteira, 1991. P. 43-52.

CONDORCET, Jean-Antoine-Nicolas de Caritat, marquis de. Cinco memórias sobre a instrução pública. Tradução e apresentação de Maria das Graças de Souza. São Paulo: UNESP, 2008.

CONDORCET, Jean-Antoine-Nicolas de Caritat, marquis de. Escritos sobre a instrução pública: Relatório e Projeto de Decreto sobre a organização da instrução pública, apresentados à Assembleia Nacional em nome do Comitê de instrução em 20 e 21 de abril de 1792. Tradução de Maria Auxiliadora Cavazotti e Lígia Regina Klein; Reflexões e notas sobre a educação. Tradução e notas Fani Goldfarb Figueira. Coleção Clássicos da educação. Campinas: Autores Associados, 2010 .

DOR, Juliette. Margery Kempe, ou comment une illetrée se comporte en clergesse non-conformiste au temps de la repression des Lollards. In: DUBOIS-NAYT, Armel; HENNEAU, Marie Élisabeth; KULESSA, Rrtraud von (Dir.). Revisiter la Querelle des femmes. Discours sur l'égalité/inégalité des sexes en Europe, de 1400 aux lendemains de la Révolution. Saint-Etienne: Université de Saint-Etienne, 2015. P. 211-224.

DUARTE, Constância Lima. Nísia Floresta: a primeira feminista do Brasil. Florianópolis: Mulheres, 2005.

DUBOIS-NAYT, Armel; HENNEAU, Marie-Élisabeth; KULESSA, Rrotraud von (Dir.). Revisiter la Querelle des femmes. Discours sur l'égalité/inégalité des sexes en Europe, de 1400 aux lendemains de la Révolution. Saint-Etienne: Université de Saint-Etienne, 2015.

FLORESTA, Nísia. Direitos das mulheres e injustiça dos homens. Capítulo I. In: DUARTE, Constância Lima. Nísia Floresta: a primeira feminista do Brasil. Florianópolis: Ed. mulheres, 2005. P. 69-88.

FRAISSE, Geneviève. Querelle, procès, controverse, les trois figures de la pensée féministe. In: VIENNOT, Éliane; PELLEGRIN, Nicole. Revisiter la 'querelle des femmes'. Discours sub l'égalité/inégalité des sexes, de 1750 aux lendemains de la Révolution. Saint-Étienne: Université de Saint-Etienne, 2012. P. 163-168.

FRANCE. Constitution de 1791. France, 1791. Disponível em: <http://www.cervantesvirtual.com/obra-visor/constitution-francaise-du-3-septembre-1791--0/ html/ffd5abb4-82bl-11df-acc7-002185ce6064_1.html\#I_2_>. Acesso em: 11 ago. 2017.

FRIEDMAN, Milton. Capitalismo e liberdade. Rio de Janeiro: Artenova, 1984.

GOUGES, Olympe. L'esclavage des noirs, ou l'heureux naufrage. France, 1786. Disponível em: <http://slavery.uga.edu/texts/literary_works/esclavage.pdf>. Acesso em: 7 set. 2017.

GOUGES, Olympe. Déclaration des droits de la femme e de la citoyenne. In: NOACK, Paul. Olympe de Gouges 1748-1793: Courtisane et militante des droits de la femme. Paris: Éd. de Fallois, 1993. P. 185-196.

Educação \& Realidade, Porto Alegre, v. 46, n. 3, e113918, 2021. 
Querela das Mulheres, Igualdade e Direito à Educação

GOURNAY, Marie de. Égalité des hommes et des femmes. In: SCRIFF, Mario. La fille d'alliance de Montaigne, Marie de Gournay. Essay suivi de 'L'égalité des hommes e des femmes' e du 'Grief des dammes', avec variantes, des notes, des appendices e un portrait. Paris: Librairie Honoré Champion, 1910a. Reimpression de l'éditon de Paris. Disponível em: <http://gallica.bnf.fr/ark:/12148/ bpt6k1105z/f5.item.zoom>. Acesso em: 26 ago. 2017.

GOURNAY, Marie de. Le grief des dammes. In: SCRIFF, Mario. La fille d'alliance de Montaigne, Marie de Gournay. Essay suivi de 'L'égalité des hommes e des femmes' e du 'Grief des dammes', avec variantes, des notes, des appendices e un portrait. Paris: Librairie Honoré Champion, 1910b. (Reimpression de l'éditon de Paris). Disponível em: <http://gallica.bnf.fr/ark:/12148/bpt6k1105z/f5.item. zoom>. Acesso em: 26 ago. 2017.

GROULT, Benoite. Le féminism au masculin. Paris: Gasset, 2010.

HAASE-DUBOSC, Danielle. La querelle des femmes au temps de la République des Lettres. Analyse du parcours européen de Lady Mary Wortley Montagu. In: DUBOIS-NAYT, Armel; HENNEAU, Marie-Élisabeth; KULESSA, Rotraud von (Dir.). Revisiter la Querelle des femmes. Discours sur l'égalité/inégalité des sexes en Europe, de 1400 aux lendemains de la Révolution. Saint-Etienne: Université de Saint-Etienne, 2015.

HANNER, June E. Emancipação do sexo feminino. A luta pelos direitos da mulher no Brasil, 1850-1940. Florianópolis: Ed. Mulheres; Santa Cruz do Sul, EDUNISC, 2003.

HENNEAU, Marie-Élisabeth. Introduction. In: DUBOIS-NAYT, Armel; HENNEAU, Marie Élisabeth; KULESSA, Rotraud von (Dir.). Revisiter la Querelle des femmes. Discours sur l'égalité/inégalité des sexes en Europe, de 1400 aux lendemains de la Révolution. Saint-Etienne: Université de Saint-Etienne, 2015. P. 9-19. HUGO, Victor. Lettre de Victor Hugo a Léon Richer. Le 8 juin 1872. France, 1872. Disponível em: <http://www.deslettres.fr/lettre-de-victor-hugo-a-leon-richerdifficile-de-composer-bonheur-de-lhomme-souffrance-de-femme/>. Acesso em: 26 ago. 2017.

KRAMNICK, Miriam Brody. Introduction. In: WOLLSTONECRAFT, Mary. Vindication of the rights of woman. Reprinted. Great Britain: The Penguin English Library, 1983. P. 7-74.

LA DÉCLARATION des Droits de l'Homme et du Citoyen. Présentée par Stéphane Rials. Paris: Hachette, 1988. (Contém os diferentes projetos de Declaração).

LABÉ, Louise. À M. C. D. B. L. (A Mademoiselle Clémence de Bourges Lyonnoize). In: DUBOIS-NAYT, Armel; DUFOUNAUD, Nicole; PAUPERT, Anne (Dir.). Revisiter la Querelle des femmes. Discours sur l'égalité/inégalité des sexes, de 1400 à 1600. Saint-Etienne: Université de Saint-Etienne, 2013. P. 133-135.

LARSEN, Anne R. A. Women's Republic of Letters: Anna Maria van Schurman, Marie de Gournay, and Female Self-Representation in Relation to the Public Sphere. Early Modern Women: An Interdisciplinary Journal, Chicago, v. 3, p. 105-126, 2008

LORRIS, Guillaume de; MEUN, Jean de. O Romance da Rosa. Tradução de Lucília Maria de Deus Mateus Rodrigues. Portugal: Publicações Europa-América, 2001.

MARSHALL, Thomas Humphrey. Cidadania, classe social e status. Rio de Janeiro: Zahar, 1967.

MILL, John-Stuart. A sujeição das mulheres. Texto integral. Tradução de Debóra Ginza. São Paulo: Escala, 2006. 
MOLIÈRE. Escola de Mulheres. 2. ed. Tradução Millôr Fernandes. Rio de Janeiro: Paz e Terra, 1997.

MORAES, Maria Lygia Quartim. Prefácio - Mary Wollstonecraft e o nascimento do feminismo. In: WOLLSTONECRAFT, Mary. Reivindicação dos direitos da mulher. Tradução Ivania Pocinho Motta. São Paulo: Boitempo, 2016. P. 7-16.

NOACK, Paul. Olympe de Gouges (1748- 1793): Courtisane et militante des droits de la femme. Paris: Éd. de Fallois, 1993.

PAUPERT, Anne. Les Débats de La Querelle: de la fin du XIIIe. Siècle à Chistine de Pizan. In: DUBOIS-NAYT, Armel; PAUPERET, Anne (Org.). Revisiter la 'querelles de femmes'. Discours sur l'égalité/inégalité des sexes, de 1400 à 1600. Saint-Etienne: Université de Saint-Étienne, 2013. P. 23-48.

PELLEGRIN, Marie-Frédérique. Édition, présentation et notes. In: POULAIN DE LA BARRE, François. De l'égalité des deux sexes. De l'éducatrion des fames. De l'excellence des hommes. Paris: Librairie Philosophique J. Vrin, 2011.

PERROT, Michelle. Des femmes rebelles: Olympe de Gouges, Flora Tristan, George Sand. Tunis: Elyzad, 2014.

PIZAN, Christine de. L’Épistre au dieu d'amour. 1399. Disponível em: <https:// www.hs-augsburg.de/harsch/gallica/Chronologie/15siecle/Christine/chr_ amor.html>. Acesso em: 27 nov. 2017.

PONTES DE MIRANDA, Francisco. Direito à educação. Rio de Janeiro: Alba, $1933 \mathrm{a}$

PONTES DE MIRANDA, Francisco. Os Novos Direito do Homem. Rio de Janeiro: Alba, 1933b.

POULAIN DE LA BARRE, François. De l'égalité des deus sexes. De l'éducation des dames. De l'excellence des hommes. Édition, présentation e notes para Marie-Frédérique Pellegrin. Paris: Librairie Philosophique J. Vrin, 2011.

RIALS, Stéphane (Prés.). La Déclarations des Droits de l'Homme et du Citoyen. Collection Pluriel, dirigée par George Liébert. Paris: Hachette, 1988.

SCOTT, Joan W. Os usos da imaginação: Olympe de Gouges na Revolução Francesa. In: SCOTT, Joan W. A cidadã paradoxal. As feministas francesas e os direitos do homem. Tradução Élvio Antônio Funck. Florianópolis: Mulheres, 2002. P. 49-104.

SCRIFF, Mario. La fille d'alliance de Montaigne, Marie de Gournay. Essay suivi de 'L'égalité des hommes e les femmes' e du 'Grief des dammes', avec variantes, des notes, des appendices e un portrait. Genève: Statkine Reprints, 1978. (Reimpression de l'éditon de Paris, Librairie Honoré Champion, 1910). Disponível em: <http://gallica.bnf.fr/ark:/12148/bpt6k1105z/f5.item.zoom>. Acesso em: 26 ago. 2017.

STUURMAN, Siep. François Poulain de la Barre and the Invention of Modern Equality. Cambridge, Massachusetts: Harvard University Press, 2004.

SWIFT, Helen. Résister à La Rose, ou Comment défendre les femmes face au spectre de Jean de Meun. In: DUBOIS-NAYT, Armel; DUFOURNEAU, Nicole; PAUPERET, Anne (Dir.). Revisiter la 'querelle des femmes'. Discours sur l'égalité/inégalité des sexes, de 1400 à 1600 . Saint-Etienne: Université de SaintEtienne, 2013. P. 49-61.

TELLES, Norma. Escritoras, escritas, escrituras. In: DEL PRIORE, Mary (Org.). História das mulheres no Brasil. São Paulo: Contexto, 2002. P. 401-442. 
Querela das Mulheres, Igualdade e Direito à Educação

UNITED STATES. Declaration of Independence. A Transcription. Philadelphia, 1776. Disponível em: <https://www.archives.gov/founding-docs/declarationtranscript>. Acesso em: 15 maio 2017.

VIENNOT, Éliane. Revisiter la 'querele des femmes': mais de quoi parle-t-on? In: VIENNOT, Éliane; PELLEGRIN, Nicole. Revisiter la 'querelle des femmes'. Discours sub l'égalité/inégalité des sexes, de 1750 aux lendemains de la Révolution. Saint-Étienne: Université de Saint-Etienne, 2012. P. 7-29.

VIENNOT, Éliane. Louise Labé aux femmes de son temps: Yes we can (1555) In: DUBOIS-NAYT, Armel; HENNEAU, Marie-Élisabeth; KULESSA, Rotraud von (Dir.). Revisiter la Querelle des femmes. Discours sur l'égalité/inégalité des sexes en Europe, de 1400 aux lendemains de la Révolution. Saint-Etienne: Université de Saint-Etienne, 2013. P. 133.

WOLLSTONECRAFT, Mary. Vindication of the rights of woman. Reprinted. London: Penguin Books, 1983.

WOLLSTONECRAFT, Mary. Reivindicação dos direitos da mulher. Tradução Ivania Pocinho Motta. São Paulo: Boitempo, 2016.

Alceu Ravanello Ferraro (1935-2019) graduou-se em Filosofia, pela Universidade Regional do Noroeste do Estado do Rio Grande do Sul (1971), e em Teologia, pela Pontifícia Universidade Gregoriana (1960). Mestre (1963) e doutor (1969) em Ciências Sociais / Sociologia pela Pontifícia Universidade Gregoriana, Roma/Itália. Foi membro do Comitê de Pesquisa do INEP, do Comitê de Assessor do CNPq e do Comitê Assessor da CAPES, área de Educação. Foi Presidente da Associação Nacional de Pós-Graduação e Pesquisa em Educação/ANPEd (1989/91 e 1991/93), Pesquisador do CNPq, Consultor ad hoc do CNPq e CAPES. Foi membro do Comitê Assessor da Área de Psicologia e Educação da FAPERGS (2006 a 2009). Foi professor titular do Departamento de Estudos Básicos da Faculdade de Educação da Universidade Federal do Rio Grande do Sul (UFRGS). Coordenou o Programa de Pós-Graduação em Educação do Centro Universitário La Salle (Unilasalle) Canoas/RS (2007-2008). Atuou ainda como docente convidado no Programa de Pós-Graduação em Educação da UFRGS. Pesquisou principalmente os seguintes temas: analfabetismo/alfabetização, escolarização, letramento e políticas públicas, no Brasil e Rio Grande do Sul.

ORCID: http://orcid.org/0000-0002-2546-4501

E-mail: aferraro@ufrgs.br

Editor-responsável: Fabiana de Amorim Marcello

Este é um artigo de acesso aberto distribuído sob os termos de uma Licença Creative Commons Atribuição 4.0 Internacional. Disponível em: <http:// creativecommons.org/licenses/by/4.0>. 